\title{
Obituaries
}

Obituaries should be submitted by email to Jadene Doak at jadene.doak@springernature.com

All submitted obituaries should be 400 words maximum in length (apart from obituaries for past presidents of the BDA where the length should be 800 words).

Content of the obituary is down to the individual author, and the approval of the family should be given for the obituary prior to submission to the BDJ.

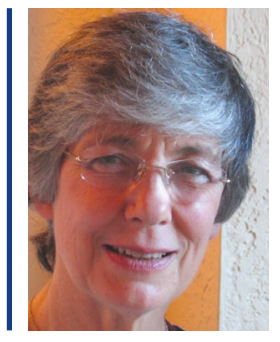

\section{Mary Catherine Stark Codling (McFarlane)}

1937-2021

Mary Codling, better known to her patients and many dental friends as Mary McFarlane, was born in 1937. She and her brother Ian were brought up in Blackburn in the house where her father William McFarlane ran his dental practice. Dentistry was in the genes, and the siblings both ended up following in their father's footsteps.

Mary started her degree in September 1955 , joining a group of dental students at the Turner Dental School, Manchester University, who, as they were embarking on a new course, were named 'Guinea Pigs' by the then Dean. On graduation in 1960, a long and enduring group 'the Guinea Pig Club' was formed.

On qualifying, Mary worked in the community dental service, before joining her father in the family dental practice, continuing to build the practice after her father retired.

Despite marriage and the arrival of three daughters and the acquisition of her wonderful historic home, Mary continued her dental career. She was always a staunch supporter of the Ribble Section of the BDA and was North Western Branch President as well as a member of the LDC.

Fascinated by dental history, Mary was an active member of the Lindsay Society and inherited an extensive historic dental instrument collection - one that is now in need of a new home!

Throughout her life, Mary continued to develop and expand her dental knowledge, attending numerous courses in the UK and beyond. As part of general dentistry, she carried out simple orthodontics, using removable appliances. Mary later made time, despite continuing with her main practice, to undertake additional training to seek to become a Specialist (NHS) Orthodontist which she proudly achieved at the age of 60 . When others might be retiring, she gave up general dental practice but worked as a Specialist Orthodontist in two practices and the CDS for a further 13 years.

Retirement meant travelling and keeping up with friends and family in the UK and abroad. It meant time to enjoy her grandchildren, to develop her interest in music, going to concerts and joining a choir, and not to mention continuing her lifelong interest in the history of her home, Martholme.

In the last years of her life Parkinson's disease combined with mobility problems meant Mary moved to a nursing home - albeit with regular jaunts to the nearby pub. Mary died peacefully surrounded by family on 14 August 2021.

Maire Morton, Geoff Garnett, Phillipa Codling, Emma Hawker

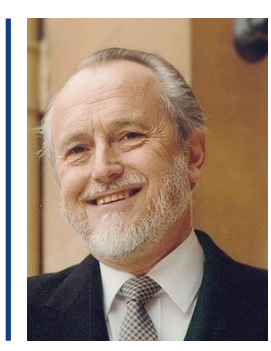

\section{Keith Millman MBE}

1932-2021

Keith Millman was born in Gunnislake, Cornwall in 1932. He graduated from Guy's in 1957, and after a house job had to choose between academia or practical dentistry. $\mathrm{He}$ was advised to do a 'taster' in general dental practice. He often said this was the best piece of advice he ever received. After brief assistant posts in North Wales and Somerset, he set up a practice in Kingsbridge, South Devon. This became enormously successful and patients would travel from far and wide to seek Keith's expertise.
He soon became involved in the activities of the Western Counties Branch of the BDA and was elected the Branch Secretary in 1968. He was a member of the BDA's Representative Board for 20 years, and during that time, he served on the General Dental Services Committee, the Ethics Committee, and from 1977 to 1985 , he was a BDA Council member. He chaired the GDSC's Working Party on 'Informal Procedures for the Sick Dentist' which heralded the Dentists Health Support Trust.

He retired from being the Branch Secretary in 1974 but remained a Branch Council member for many years, helping to organise the Annual BDA Conference in Torquay in 1975. In 1978, he was the Western Counties Branch President in its Centenary Year. For 25 years, he was a member of the Local Dental Committee, and its Chairman from 1979-1983. Over this period he served in various capacities on the SW Regional Health Authority, the Devon Heath Authority and the Devon FPC.

In 1988, he was appointed MBE by the Queen for services to dentistry and, in 1996, the Fellowship of the British Dental Association.

Early retirement from practice followed a stroke while skiing in France in 1996, and this allowed him to devote more time to his passion, photography. He contributed pictures to many exhibitions, particularly macro-photography of plants and insects. In Kingsbridge, he was an active member of the Operatic Society, having sung as a boy soprano at school, and with the Royal Choral Society under Sir Malcolm Sargent whilst at Guy's.

In all that he achieved, he was wonderfully supported by his wife, Tricia, who he married in 1957. Sadly, she passed away not long after their Diamond wedding anniversary. They had three children: Andrew, Adrian and Valerie. He will be greatly missed by them, his six grandchildren, and by his many friends, colleagues and patients.

William Beare and John M. G. Hunt 